\title{
The Potential Applications of Optical Dating to the Sandy Uplands of East Texas and Northwest Louisiana
}

Charles D. Frederick

Mark D. Bateman

Follow this and additional works at: https://scholarworks.sfasu.edu/ita

Part of the American Material Culture Commons, Archaeological Anthropology Commons, Environmental Studies Commons, Other American Studies Commons, Other Arts and Humanities Commons, Other History of Art, Architecture, and Archaeology Commons, and the United States History Commons

Tell us how this article helped you.

This Article is brought to you for free and open access by the Center for Regional Heritage Research at SFA ScholarWorks. It has been accepted for inclusion in Index of Texas Archaeology: Open Access Gray Literature from the Lone Star State by an authorized editor of SFA ScholarWorks. For more information, please contact cdsscholarworks@sfasu.edu. 
The Potential Applications of Optical Dating to the Sandy Uplands of East Texas and Northwest Louisiana

\section{Creative Commons License}

(c) (1) (8)

This work is licensed under a Creative Commons Attribution-NonCommercial 4.0 International License 


\title{
THE POTENTIAL APPLICATIONS OF OPTICAL DATING TO THE SANDY UPLANDS OF EAST TEXAS AND NORTHWEST LOUISIANA.
}

\author{
Charles D. Frederick and Mark D. Bateman
}

\begin{abstract}
The fine, sandy soils of East Texas and Northwest Louisiana have been the source of archaeological debate for some time. This discourse concerns the mode of burial of cultural material in the easily eroded soils and the mechanics of recent (Holocene) landform evolution. Because these deposits are typically well-drained, organic matter does not preserve well, thus hindering the dating of the geomorphic events that figure prominently in their development and the prehistoric occupations which lie buried throughout uplands of this region. A relatively new dating technique, optical dating, has much to offer this region and the archaeological community as it measures the period of time that has elapsed since sand grains were last exposed to sunlight. Hence, it directly dates the time of sediment transportation and deposition. This method is therefore applicable to a number of archaeological and geomorphic processes which may not be dated by traditional methods, owing to the lack of organic matter suitable for radiocarbon dating. In geomorphic contexts, optical dating may be preferred over radiocarbon as it directly dates the time of sedimentation rather than the age of organic matter in features such as buried soils that may be significantly different from the geomorphic event which fossilized the soil.
\end{abstract}

\section{INTRODUCTION}

The purpose of this paper is to draw attention to a relatively new dating technique which holds considerable potential for dating cultural events and natural landscape processes in East Texas and Northwest Louisiana. Until recently, scientific dating methods applicable to Northeast Texas archaeology have been most often confined to radiocarbon and, rarely, thermoluminescence dating. However, because of the well-drained and sandy nature of the upland soils in many parts of East Texas, radiocarbon dating is hindered by the relatively poor preservation of organic malter. Sites where significant amounts of organic matter are recovered during excavation are generally young (Late Archaic or younger; see Fields [1995:303 and Figure 2] for a histogram of radiocarbon ages from sites in the Post Oak Savannah, and Fields [1995:318-319] for a discussion of the range of subsistence foods recovered from archaeological sites of this region), and virtually non-existent for older sites. Hence, even with the advent of AMS radiocarbon dating, which permits the assay of very small pieces of organic carbon, many sites older than 3,000 to 4,000 years (and some young ones as well) will be difficult to date by conventional means.

Optical dating has been developed as a dating method over the last decade and uses the grains of sand as clocks or chronometers in order to determine the period of time that has elapsed since the sand grains were last exposed to sunlight. Because it relies upon sand grains instead of organic matter, this method is ideally suited to applications in the sandy soils of upland East Texas. Sand does not (at least when we last checked) easily decompose. Instead it simply moves around, and often builds up to amazing depths ( $>4 \mathrm{~m}$ in some archaeological sites). 


\section{WHAT IS OPTICAL DATING?}

As with many radiometric dating techniques, optical dating has four basic principles: a time dependant signal, a zeroing mechanism, a means of measuring the signal, and a means of relating the signal to calendar years.

1. The time dependant signal: The minerals that sand is usually composed of have small defects within their crystals which may trap energy when exposed to ionizing radiation. Most sediments have low amounts of uranium, thorium, and potassium which with cosmic radiation subject sediments to low level ionizing radiation (Figure 1). As these main naturally occurring radioactive elements all have very long half-lives, the low-level ionizing radiation they emit can be assumed to be constant. The amount of trapped energy in the crystals is therefore a time dependant signal which will increase with time until a saturation level is reached.

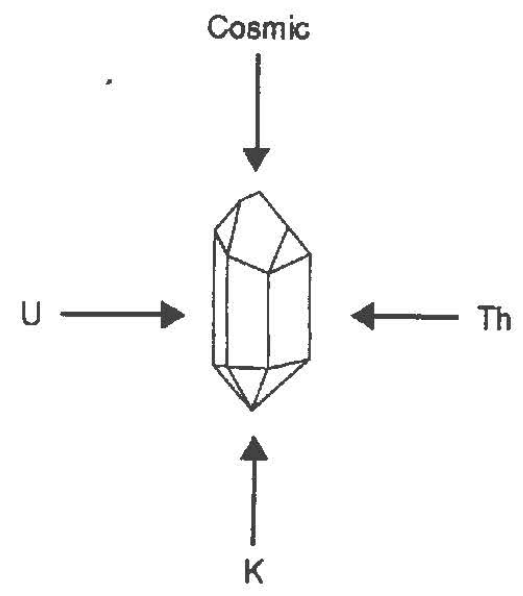

Figure 1. The main natural contributors to the ionizing radiation flux received by sediments.

2. The Zeroing Mechanism: The time dependant signal will build up with time until the traps are emptied either by exposure to sunlight, a process known as bleaching, heat, or stimulation in the laboratory (Figure 2). During sediment erosion, transportation, and deposition, natural exposure to sunlight resets the 'timeclock,' which only restarts on sediment burial. This zeroing thus allows specific depositional events to be dated. Unlike thermoluminescence (TL), the fore-runner of optical dating, only the light sensitive signal which is zero after full bleaching is measured. TL has an unbleachable signal associated with it which requires additional measurements to quantify. 


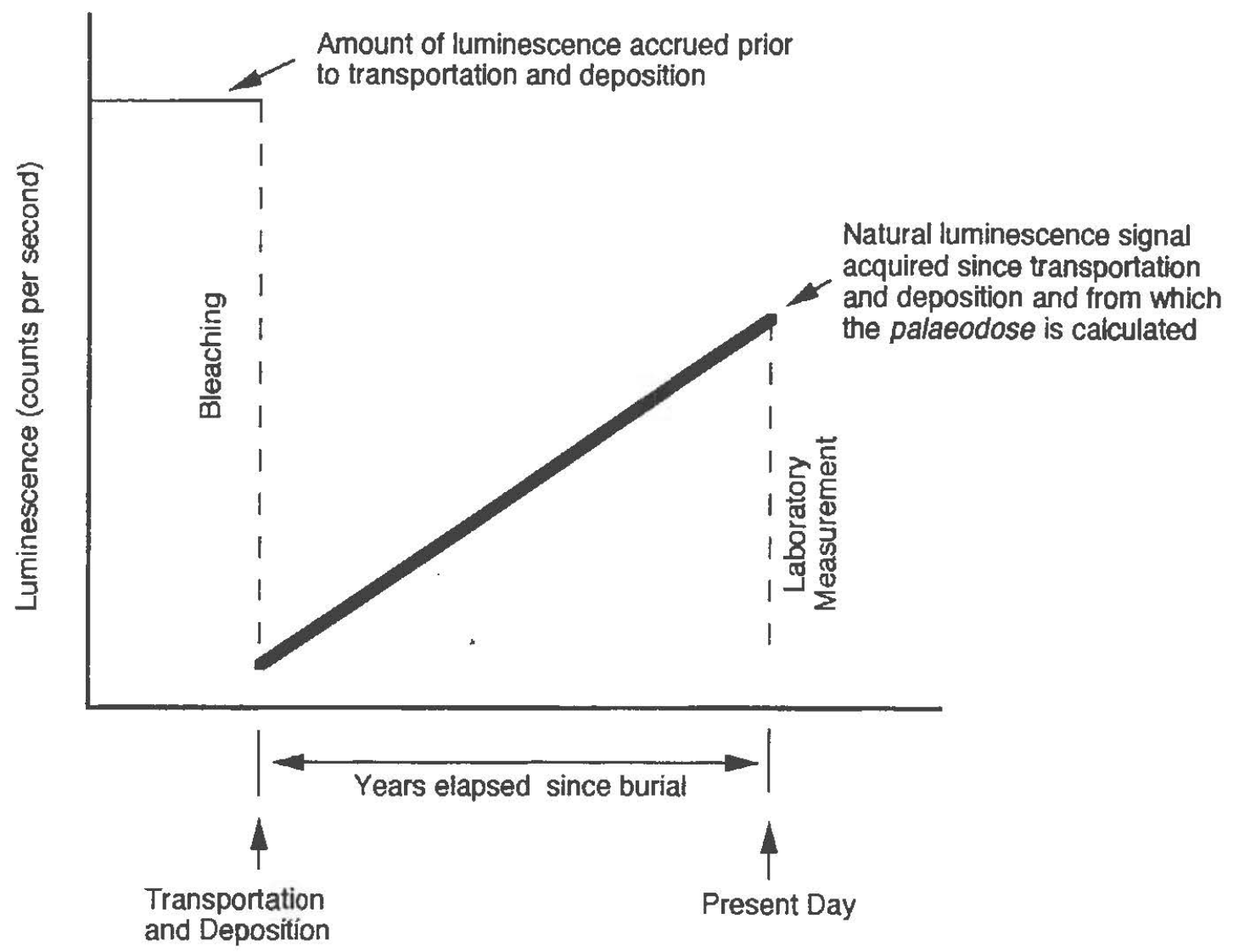

Figure 2. Schematic illustration of the general relationship between bleaching of a sediment sample during transportation and deposition and the subsequent accumulation of a luminescence signal or palaeodose (modified from Aitken 1998:Figure 1.1).

3. A means to measure the signal: When exposed to light or heat, crystals give up their trapped charge and emit luminescence (light) (Figure 3). Using sensitive photomultiplier technology under laboratory conditions, the amount of light released as luminescence may be measured and then related to the amount of radiation to which the sample was exposed since it was last bleached. Unfortunately, each sample has its own efficiency of storing trapped charge so relating luminescence to total radiation since burial is not trivial. It is done by dividing a sample into sub-groups. One sub-group has the amount of natural acquired luminescence measured. Other groups are given, in addition to their naturally acquired dose, various known amounts of radiation in the laboratory and then these levels or luminescence are measured and compared to the naturally acquired luminescence level (Figure 4). In this way it is possible to establish the amount of radiation, measured in Grays (Gy), required to form the natural luminescence signal, a property known as the palaeodose. 


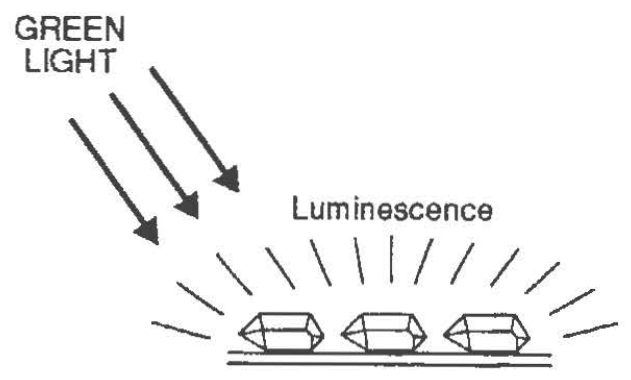

Figure 3. Schematic representation of OSL stimulation of sand grains.

(a)

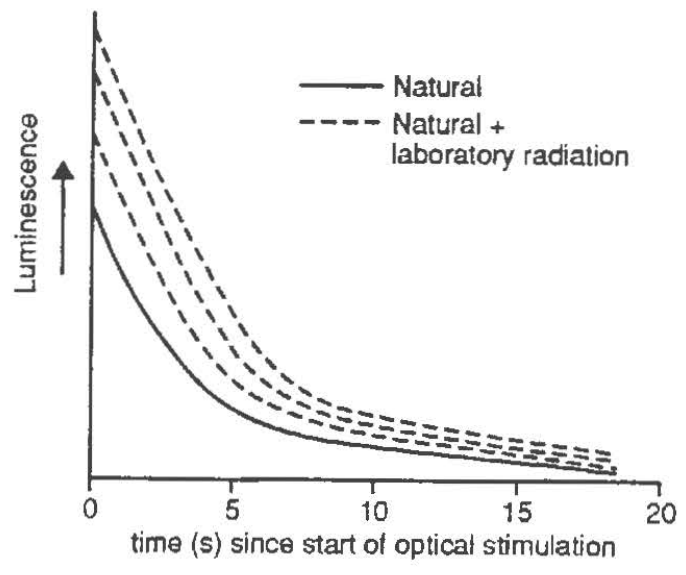

(b)

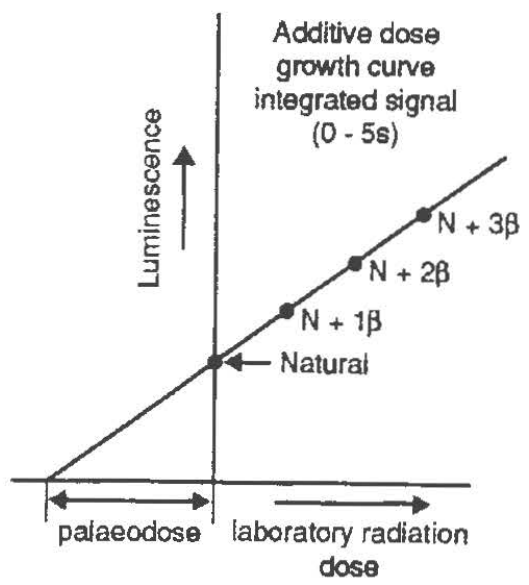

Figure 4. (a) Illustration of how with stimulation time the amount of OSL decays and how OSL signal increases with the addition of laboratory radiation; (b) Using the integral OSL counts from the previous graph points $(\mathrm{N}, \mathrm{N}+1 \mathrm{~b}, \mathrm{~N}+2 \mathrm{~b}, \mathrm{~N}+3 \mathrm{~b})$ can be plotted and the palaeodose can be calculated.

4. Relating the signal to calendaryears: Once the palaeodose is known, the period of time that has elapsed since the sample was last exposed to sunlight may be calculated from the following equation:

Age $(\mathrm{a})=\quad$ Paleodose $(\mathrm{Gy})$

Dose Rate (Gy/a)

[Eq. 1]

The Dose Rate, measured in Grays per year (Gy/a), is determined from the concentration of radioactive elements found in proximity to the sample, and the level of cosmogenic radiation which attenuates rapidly with the depth of the sediment. The dose rate may be directly measured in the field using a 
field gamma-spectrometry system, or determined by elemental analysis of the sediment within the sample. The former is generally more accurate than the latter as it measures any inhomogeneities present within a $0.5 \mathrm{~m}$ radius of the sample.

In practice, the actual calculation of the age is considerably more complex than expressed in equation 1, but this general relationship is the fundamental basis of the dating method. A summary of the steps to obtaining an optical date is shown in Figure 5. Currently, optical luminescence dating is capable of providing ages between several decades and half a million years old, but the actual age range is limited by the attributes of the sample and the methods used (Aitken 1998:2). Optical dates are usually presented as the number of calendar years that have elapsed since burial to the year of measurement. Associated errors with the optical dates are usually at the one standard deviation level and range from 5 percent for a well bleached sediment to +25 percent for a poorly bleached sample. The accuracy of the technique has been successfully tested in a number of contexts against other independent dating techniques (e.g., Stokes 1991; Berger 1992; Clarke et al 1996; Richardson et al. 1997; Stokes and Gaylord 1993; Bateman n.d.; Bateman et al. n.d), so it is well established as a dating tool.

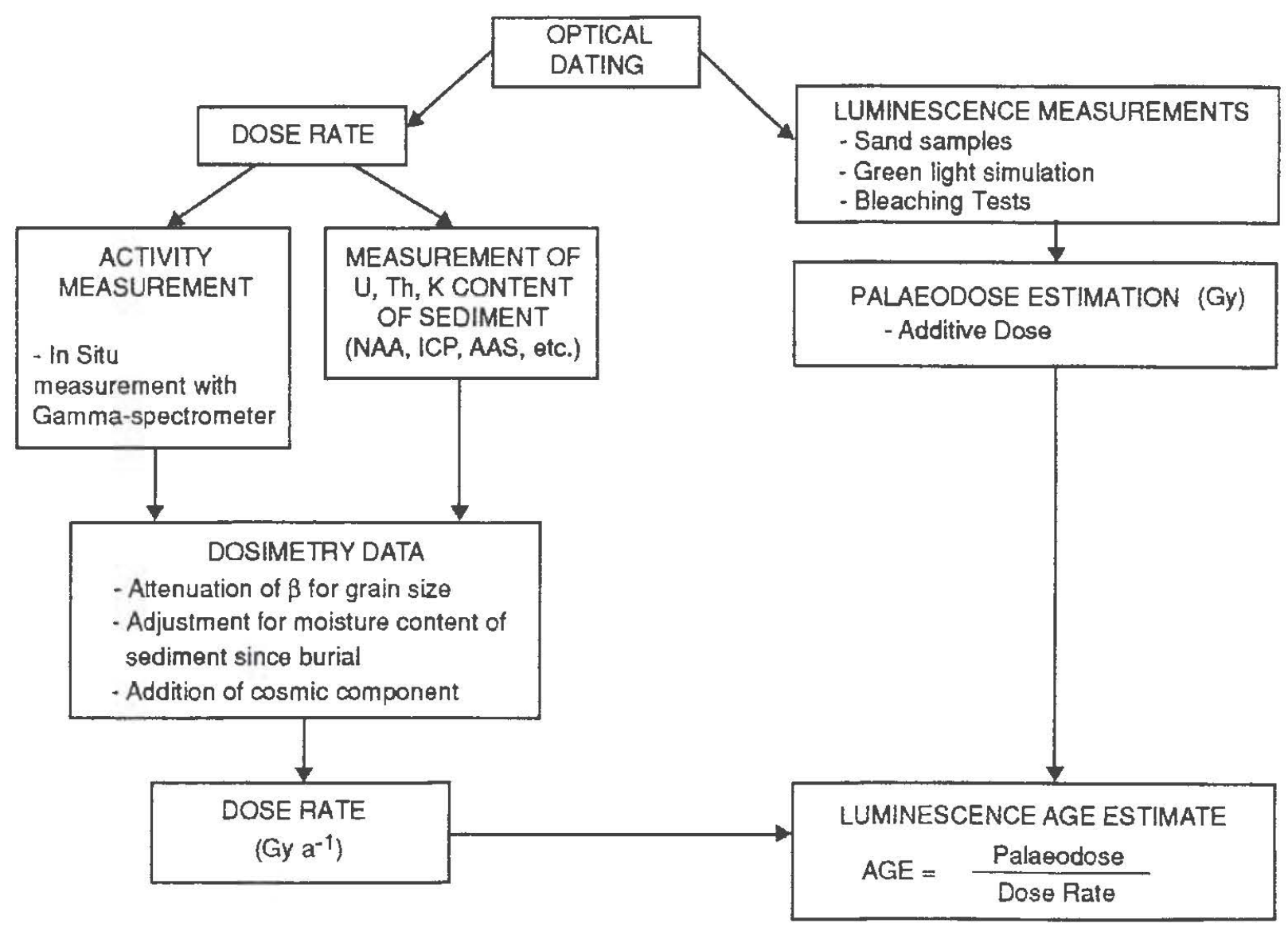

Figure 5. A flow-chart of the steps required to derive an optical date. 
There are a number of specific forms of optical dating presently available relating to the method of stimulation used to obtain the luminescence signal. These include infra-red stimulated luminescence (IRSL) and, perhaps the most commonly known, optically stimulated luminescence (OSL). The former relies on extracting feldspar grains from sediments and applying light of an infra-red light wavelength to stimulate the feldspars into de-trapping (releasing) their energy and emitting luminescence. The latter use green or blue/green wavelengths to stimulate quartz into emitting luminescence, either using filtered halogen light or a laser. With both IRSL and OSL, monitoring of the resultant luminescence has to be carefully filtered to prevent measurement of the stimulation light (Figure 6). Whilst both IRSL and OSL have been demonstrated to work, the authors advocate the use of OSL because quartz is more abundant, does not weather so easily, is not radioactive (unlike potassium feldspars which self irradiation themselves), and finally certain feldspar minerals have been found to loose part of their time dependant signal through fading (Wintle 1977). Likewise the authors' preferred option is to apply optical dating to sand-sized sediments as this facilitates quartz cleaning and extraction.

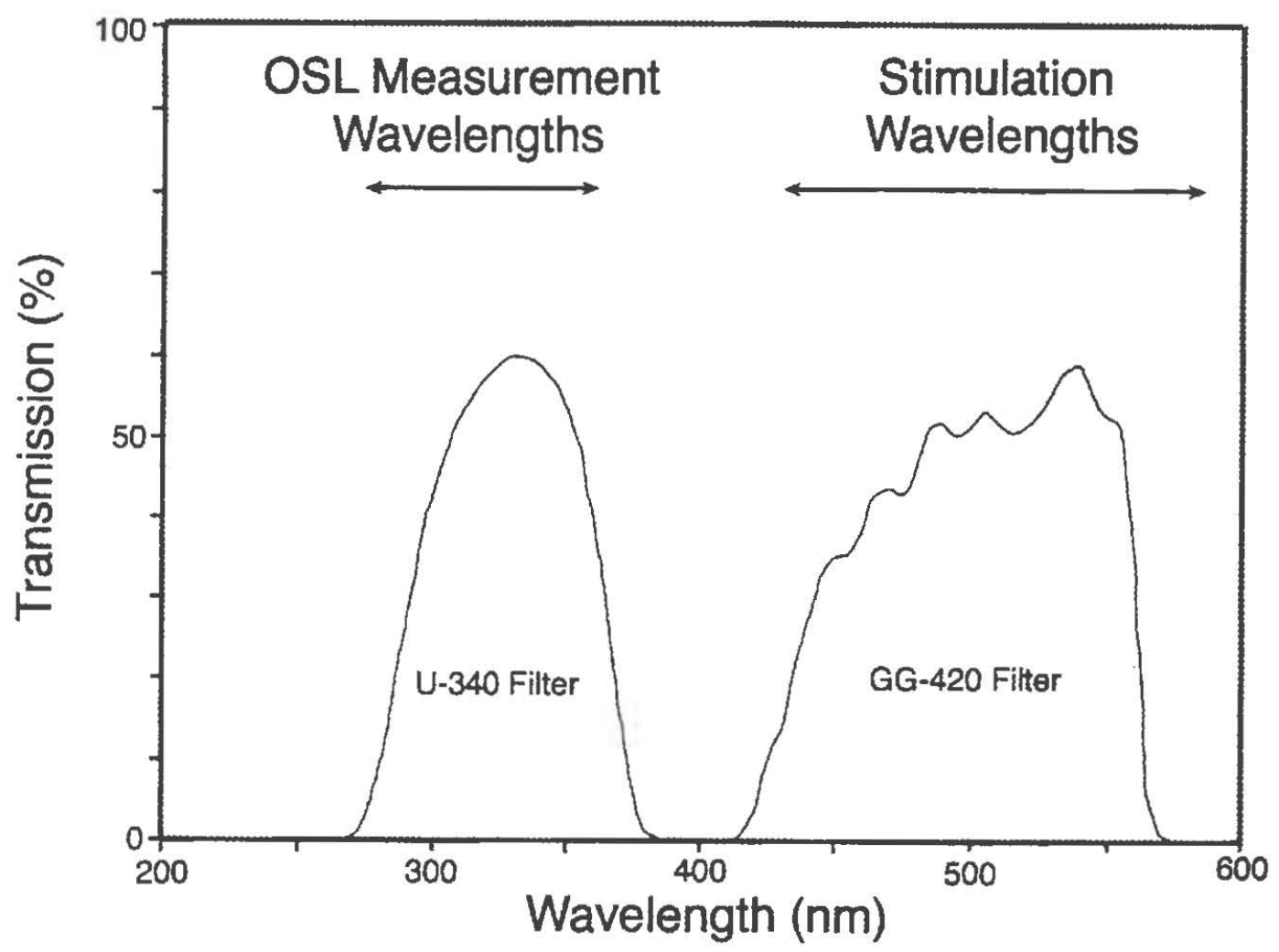

Figure 6. Illustrating how the use of filters is need differentiate between the stimulating light and the resultant luminescence measured. 


\section{Potential Problems}

A number of factors may adversely influence the validity of OSL dates. In general terms, any process that influences the dose rate, integrity of the sample, or bleaching may lead to erroneous ages. Some examples of these include: partial or incomplete bleaching, leaching of radioactive elements in the soil/sediment, variations in the amount of pore water through time, and bioturbation.

Perhaps the most significant problem is partial bleaching. If the entire sample is not adequately bleached, then the age calculated from the natural luminescence signal will be too old or the data scattered, causing the error limits on the age estimate to go through the roof. Partial bleaching is most often a problem in settings where exposure to sunlight during transportation is not assured, such as during slope processes such as creep, or in the flood waters of streams with high suspended sediment loads. The advantage of OSL over its fore-runner thermoluminescence (TL) is that only a 5 second sunlight exposure reduces the OSL signal in quartz down to 1 percent of its initial level compared to $>24$ hours of exposure need to achieve the same level of bleaching for TL (Godfrey-Smith et al. 1988). Thus, the chances of successfully applying OSL to non-acolian contexts is much higher. Laboratory procedures have now been developed which make it possible to check that a sample has been properly exposed to sunlight prior to burial, and allowing the rejection of unreliable samples (Duller 1995; Clarke 1996).

Variations in the concentration of radioactive elements in proximity to the sample through time may lead to inaccurate dose rate calculations and result in erroneous ages. The most common problem is the leaching or removal of radioactive elements such as potassium. In most applications using optical dates, the decay chains of uranium and thorium are assumed to be in isotopic equilibrium or that leaching has occurred prior to deposition and so variation is not deemed a problem. Should there be strong evidence that disequilibrium has occurred it can be tested by measuring the relative activities of daughter isotopes in the uranium and thorium decay chains.

The dose rate may also be affected by changes in the concentration of pore water in the sample through time. As water attenuates the level of radiation received by samples, its presence affects the dose rate calculation. This is compensated for in calculations by measuring the moisture content of the sample at the time of collection. However, significant departures from this value may result in small variations in the dose rate and therefore affect the validity of the calculated age as can be seen in Table 1 . In practice, the average palaeomoisture value will not have varied so markedly. Use of geomorphic evidence of significant variations away from the present-day moisture contents can by used to mitigate such problems and wide error margins are usually built in to account for seasonal fluctuations away from the moisture level at the time of sampling.

Another process which may influence the age is mixing of the sediment following deposition, a process often referred to as pedoturbation. There are a number of vectors of pedoturbation in East Texas and Northwest Louisiana which may influence the validity of OSL dates. The most obvious are burrowing animals such as gophers, worms and ants, but there are others as well. The degree to which these processes will affect OSL dates is determined by the extent and frequency of disturbance. In many cases it may be possible to see obvious signs of disturbance (e.g., krotovina) especially at the interface of deposits of different lithology (composition), but these features may be much less apparent in homogeneous deposits such as the massive sands that blanket the uplands of these regions. In reality, it may not be possible to completely avoid disturbance, except by relatively rapid burial. The most common agents of pedoturbation in East Texas are known to operate near the surface (top 30 to $50 \mathrm{~cm}$ ) so rapidly buried deposits may hold the greatest integrity. 
Table 1. The Maximum Effect of Paleomoisture for Samples from a range of locations in Texas and Mexico covering a range of antiquities

\begin{tabular}{|l|ll|lc|}
\hline Sample & $\begin{array}{l}\text { Min } \\
\text { Moisture } \\
\text { Dose Kate } \\
(\mathrm{Gy} / \mathrm{ka})\end{array}$ & $\begin{array}{l}\text { Max } \\
\text { Moisture } \\
\text { Dose Kate } \\
(\mathrm{Gy} / \mathrm{ka})\end{array}$ & $\begin{array}{l}\text { Min Age } \\
\text { (ka) }\end{array}$ & $\begin{array}{l}\text { Max Age } \\
\text { (ka) }\end{array}$ \\
\hline Shfd97093 & 5.12 & 3.71 & 0.20 & 0.27 \\
Shfd97082 & 3.60 & 2.62 & 1.21 & 1.66 \\
Shfd97083 & 3.83 & 2.78 & 4.28 & 5.90 \\
Shfd97091 & 4.43 & 3.20 & 6.57 & 9.08 \\
Shfd98013 & 2.85 & 2.08 & 8.70 & 11.93 \\
Shfd98014 & 2.77 & 2.02 & 17.47 & 23.94 \\
\hline
\end{tabular}

Note: The dose rate and the subsequent age calculations are based on palaeomoisture values of 0 percent wet weight and a experimentally determined saturation level of 25 percent wet weight (Bateman 1995).

\section{APPLICATIONS}

Situations where OSL dating is applicable in East Texas are numerous, owing to the character of the geology, soils, and in some instances, past cultural practices. In general terms, wherever sand has been exposed to the sun during a period of activity of interest, such as either natural erosion and sedimentation or cultural acts such as mound building. The following section lists a number of specific settings and situations which may be conducive to OSL dating. Most (but not all) of these suggestions have not been dated before, but rather are situations where the conditions for sufficient bleaching and resetting of the OSL dating clock may have been achieved. Hence, conservative readers may which to consider them testable hypotheses.

\section{Geomorphic activity}

There are a number of geomorphic contexts which may be amenable to OSL dating. As mentioned previously, the loose sandy deposits that mantle upland surfaces of Fast Texas and northwest Louisiana (sometimes shortened to "the sandy mantle") often contain archaeological materials at great depths (upwards of $4 \mathrm{~m}$ in places). It has been argued that these deposits are a distinct, Holocene-age lithostratigraphic unit, informally named the Big Brushy formation by Bianchi (1984:463-467) in west-central Louisiana following geomorphic work at 16VN24, the Big Brushy site, Fort Polk Louisiana (Servello 1983; Guderjan and Morehead 1983:859-936). This unit has been correlated into Texas principally by Paul Heinrich in a number of Prewitt and Associates projects in east Texas (e.g., Fields 1987). Debate concerning the age, origin and validity of this unit remains lively (see Perttula et al. 1986:206-209; Bousman and Fields 1991:5-20; Thoms 1995:107132; Thoms et al. 1994:167-185) and inconclusive.

\section{Slope Settings}

Observations of the modern landscape and the deep burial of cultural materials indicate that these sandy upland deposits are prone to rapid redistribution during periods of deforestation, when gully-fans systems may form on slopes and in small-order drainages. This mode of sediment redistribution is most likely responsible for the formation of some of the buried soils which are found throughout the upland slopes of this region. Dating 
these events is typically difficult as detrital organic matter which is contemporaneous with the slope activity is not preserved. The most common means of dating these events is radiocarbon assay of organic matter in the buried soils or redeposited charcoal usually from prehistoric occupations. Because of the nature of soil organic carbon, radiocarbon ages derived from it do not pertain to the period of geomorphic activity of interest. Instead, such dates provide an indication of how long organic matter resides in the soil (often referred to as the mean residence time) and may considerably predate the geomorphic event which created the paleosol. Likewise, redeposited charcoal will also predate the geomorphic activity of interest. In such settings, OSL dating may be used to directly date the period of sedimentation, and therefore may offer a more precise option than radiocarbon dating.

Colluvial deposits have been successfully dated by OSL dating in several settings ranging from south Africa (e.g., Wintle et al. 1995; Clarke et al 1996) to Germany (e.g., Lang and Wagner 1996, 1997). The first person to employ OSL dating in East Texas is Robert Rogers of Espey, Huston \& Associates, Inc. (now PBS \& J, Inc.) who has used OSL together with radiocarbon dating on a number of projects with generally good results (e.g., Rogers 1994, 1995a, 1995b, and personal communication).

\section{Ridge Crests}

In addition to the more conventional slope processes, one of the perpetual geomorphic issues in this landscape centers around the possible presence of an eolian component within upland settings. The existence of deeply buried sites on ridge or hill crests has been cited as evidence of such activity. Demonstrating the existence of such deposits is very problematic given the lack of datable materials and the relative homogeneity of the deposits. OSL dating may be an effective dating tool in such settings because bleaching is assured during aeolian transportation. Furthermore, the analytical framework for evaluating such "overthickened sands" on hill top and ridge crest settings is one in which OSL dating may provide some clues to the depositional process. Where thick sands are present on the highest portions of the local landscape, colluvial processes may be safely excluded and the existence of such sands reduced to two origins: (1) eolian deposition, and (2) weathering of ancient (Tertiary) sediments. Loose sands generated through the down-weathering of ancient sediments should yield very old OSL dates (basically saturated luminescence signals) whereas eolian deposits will yield much younger (presumably) Holocene ages. In the one instance where this has been performed, a tightly sampled series of OSL dates in a $1 \mathrm{~m}$ thick section of unconsolidated sands on a hill top in Lee County, Texas, yielded Holocene ages in proper stratigraphic sequence. Conversely, the B-horizon at depth yielded considerably older (Late Pleistocene) ages (Frederick et al. n.d.). Although this sequence strongly suggests that the eolian hypothesis is correct, the most rigorous test will be the dating of very thick $(>3 \mathrm{~m})$ sand accumulations where pedoturbation of the deposits can be completely ruled out as a means of bleaching.

\section{Alluvial deposits}

Luminescence dating is still under evaluation with respect to alluvial sediments. The method as it applies to alluvial deposits has been summarized by Bailiff (1992). In some situations, the distribution of fines in the water column may preclude adequate bleaching of grains, resulting in erroneous (too old) ages. Perhaps the best settings for the use of this method in alluvial environments is in floodplain settings where the water column would have been relatively shallow and the probability of bleaching highest. Given these qualifications, OSL dating has been successfully applied to alluvial deposits in NE Spain (e.g., Macklin et al. 1994), Switzerland (Preusser 1998), and the Netherlands (Duller and Törnqvist 1998). 


\section{Cultural deposits}

In addition to the aforementioned geomorphic contexts, many activities practised by prehistoric populations may have created situations amenable to dating by OSL. In particular, activities which involved the movement of sediment that would have permitted bleaching and resetting of the sand grains are the ones of interest. Conceptually, a number of cultural practices and the resultant archaeological features may qualify. For instance, pit fills, mound deposits, and other construction or occupation related activities are included in this category. The best situations are those where the deposit was rapidly buried to a depth of about $30 \mathrm{~cm}$. So mound deposits and pit fills are the obvious choices, but others may exist as well.

\section{Elements of Built Features such as Mounds}

Mounds or earth platforms afford several stratigraphic settings which may present situations conducive to OSL dating (Figure 7). The first option is the sediments buried by the mound. In settlement sites, sandy material within about $10 \mathrm{~cm}$ of the ground surface is easily disturbed by foot traffic, and this disturbance may be sufficient to reset the OSL dating clock (see point 1 on Figure 7). Where mounds were constructed by the dumping of basket loads of earth, it may be possible to discern vestiges of the individual basket dumps within the mound. Although all of the sediment in each basket may not have been bleached during excavation and transport, it is probable that the upper portion of each basket load will have been bleached following dumping (point number 2 on Figure 7). That said, given the nature of prehistoric tools for excavation, it is possible that much of the sediment in each basket load may have been sufficiently exposed to sunlight during excavation to effect bleaching as well. Either way, the upper surface of each basket load may have been sufficiently bleached by exposure to sunlight and minor amounts of foot traffic during construction. The third setting (point 3 on Figure 7) is the top and sides of the mound itself, in settings where the mound was eventually buried. This context is best suited to dating when the mound was buried by cultural or natural processes. If the mound has not been buried, exposure to sunlight will be excessive, and modern fauna may continually expose the near surface sediment to sunlight resulting in ages that are too young owing to pedoturbation and mixing which continually results in bleaching.

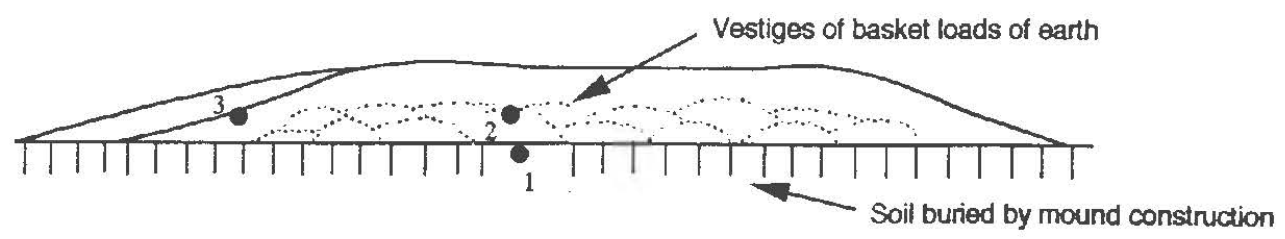

Figure 7. Cartoon illustrating the stratigraphic settings associated with mound archaeosediments potentially conducive to OSL dating.

Pits and pit fills

In some instances, the sediment filling pits may have been sufficiently exposed to sunlight to permit resetting (e.g., Lang and Wagner 1996). Where possible, it is preferable to select pits which were (as best as can be determined today) located outside of structures. In many cases, the infilling of pits is a gradual process, although some may have been intentionally filled with sediment during use. Either situation may permit dating. However, if one 
wishes to date the point in time when the pit was excavated, it is necessary to sample the base of the pit fill.

To date such features it is necessary to excavate only half of the feature and use the remaining pit fill for the collection of dating samples. The remainder of the fill can be removed after the OSL dating samples have been removed.

\section{$\underline{\text { Sheetwash deposits }}$}

One of the last categories of deposit that may be encountered in site context are those which have been locally reworked by overland flow during the occupation of a site. Such materials are often termed sheetwash deposits, and are most likely to be present in proximity to mounds or other mounded earth features. The thin water column responsible for sheetwash redeposition favors bleaching of the grains and should permit such deposits to be readily dated when they are found to be sufficiently buried. Although not directly pertinent to this region, this process should be most useful in tells and other large prehistoric settlement sites which have formed in part from the decomposition and subsequent redeposition of mud brick (adobe) structures.

In addition to these contexts which are elements of prehistoric sites, more recent cultural activities such as historic agriculture and concomitant wind (see Bateman 1997) or shallow water (sheetwash) reworking of sediment may potentially be dated by this method.

\section{SAMPLING AND COSTS}

Samples for OSL dating must be collected with greater care than radiocarbon samples owing to the problems associated with inadvertent exposure to sunlight. The Sheffield lab routinely uses black or dark gray (but opaque) PVC pipe with an outer diameter of about 5 $\mathrm{cm}$ ( 2 inches) and cut in lengths of about 10-15 $\mathrm{cm}$ (4-6 inches) long. These tubes are hammered into an exposure of the deposit that is to be dated, completely filling the tube. Because mixing of the sample within the tube is not desired (the ends are discarded in the lab owing to potential exposure to sunlight), it is critical that the tubes are completely filled to the end. The sample pipe is then removed from the exposure and the ends sealed with plastic lids and tape. We use a black electrical or duct tape for this purpose. After the sample pipe is removed, a small bag (ca. $200 \mathrm{~g}$ ) sample of sediment is removed from the hole for moisture determination and double bagged (preferably a ziplock bag) and sealed to ensure there will be no moisture loss. Further site information required is the longitude, latitude, altitude and sample depth from the surface to enable accurate calculation of the cosmogenic dose rate.

A number of sampling strategies can be used in contexts where full bleaching of sediment to sunlight prior to deposition cannot be guaranteed. One is to collect duplicate samples from within the same horizon to be dated. These can be independently optically dated thus checking reliability of the age estimates and enhancing the chances of sampling well-bleach sediment. Another strategy is to get the law of superposition working for you by collecting a vertical sequence of samples so that samples not conforming to the age-depth relationship can be easily identified and the results treated appropriately. In contexts where probably only a thin horizon is thought to have been well bleached adopting sampling containers of the appropriate dimensions may well help so long as the volume of sediment sample is maintained at around $500-700$ cubic $\mathrm{cm}$. However, probably the best strategy of all in these circumstances is to use independent chronological information to validate whether the optical ages have suffered from non bleaching or other problems. 
The present cost of an OSL date is roughly similar to an AMS radiocarbon date. At the time this was written the price of an OSL date at the Sheffield SCIDR lab was $£ 345$ sterling, or roughly $\$ 570$ although this price varies to take into account complexities of the context trying to be dated and number of samples submitted. For further details about OSL dating and the Sheffield Centre for International Dryland Research can be found on our web page at : http://www.shef.ac.uk/uni/academic/I-M/idry/index.html

\section{SUMMARY}

The physical basis of OSL dating is ideally suited to archaeological and geomorphological studies in the sandy uplands of East Texas and Northwest Louisiana. Where it has been applied so far, generally good results have been obtained. Its ability to provide direct dates for the period of sediment mobility in environments dominated by quartzose sand in the absence of organic matter is seeningly tailor made for the logistical problems associated with such settings. Although OSL dating may be less well suited to alluvial environments, it may still yield reasonable dates if the samples were adequately bleached during deposition. This method may also be used to aid in the solution of specific archaeological problems if applied in a selective fashion. However, in all but the most ideal contexts the errors associated with OSL dates are much larger than those that are obtained from radiocarbon. Thus OSL should be viewed as an additional dating technique to apply to conventionally problematic scenarios rather than a direct replacement for radiocarbon.

\section{REFERENCES CITED}

Aitken, M. J .

1998 An Introduction to Optical Dating:The Dating of Quaternary Sediments by the Use of Photon-Stimulated Luminescence. Oxford University Press, Oxford.

Bailiff, I. K.

1992 Luminescence dating of alluvial deposits. In Alluvial Archaeology in Britain, edited by S. Needham and M. G. Macklin, pp. 27-36. Oxbow Monograph 27. Oxbow Books, Oxford.

Bateman, M. D.

1995 A chronology of coversand deposition in Britain. Unpublished D.Phil thesis, University of Sussex.

n.d. The origin and Age of coversand in North Lincolnshire, UK. Permafrost and PeriglacialProcesses.

Bateman, M. D., D. Garton, V. Priest, and D. Sainty

1997 The dating of Linear banks at Tiln, Nottinghamshire, using thermoluminescence. East Midland Geographer 20:42-49.

Batenran, M. D., J. Murton, and W. Crowe

n.d. Reconstructing the depositional environments associated with the Late Devensian coversands around Caistor, N. Lincolnshire, UK. Submitted to Boreas in January.

Berger, G.W.

1992 Dating of volcanic ash by use of thermoluminescence. Geology 20:11-14. 
Bianchi, T. H.

1984 The Surficial Stratigraphy of State Highway 16 within the Amite River Valley. In CRMP Level II Cultural Resource Investigations along Route La. 16 between Watson and Amite, edited by A. F. Servello, pp. 416-469. Louisiana Department of Public Transportation and Development, Baton Rouge, Louisiana.

Bousman, C. B. and R. C. Fields

1991 Environmental Setting. In Excavations at the Bottoms, Rena Branch, and Moccasin Springs Sites, Jewett Mine Project, Freestone and Leon Counties, Texas, edited by R. C. FieIds, pp. 5-20. Reports of Investigations Number 82. Prewitt and Associates, Inc., Austin.

Clarke, M. L.

1996 IRSL dating of sands: bleaching characteristics at deposition inferred from the use of single aliquots. Radiation Measurements 26:611-620.

Clarke, M. L., G. A. Botha, A. G. Wintle, and J. C. Vogel

1996 Late Pleistocene episodic colluviation at Voordrag, Kwa-Zulu, Natal, South Africa. In Abstracts of the 8th International Conference on Luminescence and Electron Spin Resonance Dating, pp. 178-179. Australian National University, Canberra.

Duller, G.A.T.

1995 Luminescence dating using single aliquots: methods and applications. Radiation Measuremenis 23:217-226.

Duller, G. A. T. and T. E. Törnqvist

1998 Luminescence dating of fluvial deposits. Flag News (Newsletter of the Fluvial Archives Research Group, a research group of the Quaternary Research Association) 1(3):11-12.

Fields, R. C.

1995 The Archaeology of the Post Oak Savannah of East Texas. Bulletin of the Texas Archeological Society 66:301-330.

Fields, R. C. (editor)

1987 Excavations at the Alley Road Site (41LN149B) and the Harris Hole Site (4ILN30), Jewett Mine Project, Leon County, Texas. Reports of Investigations Number 61. Prewitt and Associates, Inc., Austin.

Frederick, C. D., R. Rogers, and M. D. Bateman

n.d. Geomorphic Processes in East Texas Upland Sand Mantles: Implications of OSL Dating of Quartz. Manuscript to be submitted to Geoarchaeology, An International Journal in November 1998.

Godfrey-Smith, D. I., D. J. Huntley, and W.-H. Chen

1988 Optical dating studies of quartz and feldspar sediment extracts. Quaternary Science Reviews 7:373-380.

Guderjan, T. H. and J. R. Morehead

1983 16VN24: A stratified multiple component site on Big Brushy Creek. In U.S.L. Fort Polk Archaeological a Survey and Cultural Resources Management Program, edited by A. F. Servello, pp. 859-936. University of Southwestern Louisiana, Lafayette, Louisiana. 
Lang, A., and G. A. Wagner.

1996 Infrared stimulated luminescence dating of archaeosediments. Archaeometry 38: 129-141.

1997 Infrared stimulated luminescence dating of Holocene colluvial sediments using 410 $\mathrm{nm}$ emission. Quaternary Geochronology (Quaternary Science Reviews) 16:393396.

Macklin, M. G., D. G. Passmore, A. C. Stevenson, B. A. Davis, and J. A. Benevente

1994 Responses of rivers and lakes to Holocene environmental change in the Alcañez region, Teruel, northeast Spain. In Effects of Environmental Change in Drylands, edited by A. C. Milligan and K. Pye, pp. 113-130. John Wiley and Sons, Chichester, England.

Perttula, T. K.

1995 The Archeology of the Pineywoods and Post Oak Savanna of Northeast Texas. Bulletin of the Texas Archeological Society 66:331-359.

Perttula, T. K., B. D. Skiles, M. B. Collins, M. C. Trachte, and F. Valdez, Jr.

1986 "This Everlasting Sand Bed": Cultural Resources Investigations at the Texas Big Sandy Project, Wood and Upshur Counties, Texas. Reports of Investigations Number 52. Prewitt and Associates, Inc., Austin.

Preusser, F.

1998 Luminescence dating of fluvial sediments: Case studies from Switzerland. Flag News (Newsletter of the Fluvial Archives Research Group, a research group of the Quaternary Research Association) 1(3):11.

Richardson, C. A., E. V. MacDonald, and A. J. Busacca

1997 Luminescence dating of loess from the northwest United States. Quaternary Science Reviews 16:1-12.

Rogers, R. M.

1994 National Register Assessment of Three Archaeological Sites at the Gibbons Creek Lignite Mine, Grimes County, Texas. Document Number 940325 . Espey, Huston \& Associates, Inc., Austin.

1995a Archaeological Investigations at the Chesser Site (41LE59), Lee County, Texas. Document Number 950209. Espey, Huston \& Associates, Inc., Austin.

1995b Archaeological Excavations at Prehsitoric Sites 4IGM166, 41GM281, and 41 GM282 at the Gibbons Creek Lignite Mine, Grimes County, Texas. Document Number 940611. Espey, Huston \& Associates, Inc., Austin.

Servello, A. F. (editor)

1983 U.S.L. Fort Polk Archaeological Survey and Cultural Resources Management Program. University of Southwestern Louisiana, Lafayette, Louisiana.

Stokes, S.

1991 Quartz-based optical dating of Weichselian coversands from eastern Netherlands. Geologie en Mijnbouw 70:327-337. 
Stokes, S. and D. R. Gaylord

1993 Optical dating of Holocene dune sands in the Ferris dune field, Wyoming. QuaternaryScience Reviews 39:274-281.

Thoms, A.

1995 Sediments and Natural Site Formation Processes at 41WT5. In The Anson Jones Plantation: Archaeological and Historical Investigations at 41WT5 and 41WT6, Washington County, Texas, edited by S. B. Carlson, pp. 107-132. Reports of Investigations No. 2. Center for Environmental Archaeology, Texas A \& M University, College Station.

Thoms, A. V., B. W. Olive, and P. Clabaugh

1994 Disarticulation of the Valley Branch Site: Landscape Evolution and Natural Site Formation Processes. In The Valley Branch Archaeological Project: Excavations at an Archaic Site (41MU55) $i$ the Cross Timbers Uplands, North Central Texas, edited by A. V. Thoms, pp. 167-185. Reports of Investigations No. 15. Archaeological Research Laboratory, Texas A \& M University, College Station.

Wintle, A. G.

1977 A detailed study of a thermoluminescent mineral exhibiting anomalous fading. Journal of Luminescence 15:385-393.

Wintle, A. G., S-H. Li, G. A. Botha, and J. C. Vogel

1995 Evaluation of luminescence-dating procedures applied to late-Holocene colluvium near St. Paul's Mission, Natal, South Africa. The Holocene 5:97-102. 